107. 心電図同期心プールSPECTによる心機能評価（特に1回拍出量定量を中心に） 静岡県立棇合病院核医学科 0 望月 守松本恭德 武澤 充 宮本 唯男

目的：Multi Gateによる心機能評洒法は、简便で非侵襲的に心㙨能パラメータ-算出が可能であるため、 広く臨床で行われているが、1回拍出量等その絶対值は必ずしす正確とは言い難い。最近、我 々は心電図同期心ブ - ISPECTを行ない、従来検查法と比較し良好な結果を得たので報告する。

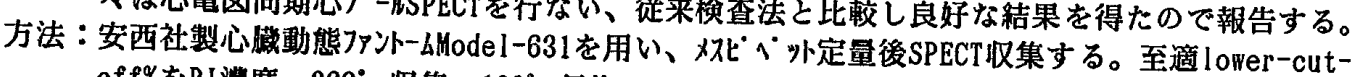

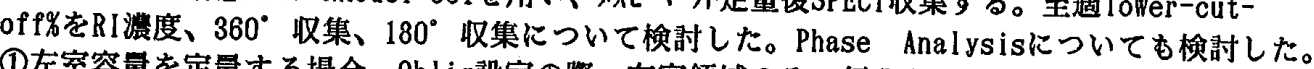

結語：(1)左室容量を定量する場合、Obliq設定の際、左空領域のみで行うか、Maskする必要がある。 (2) Coronal各SliceにおけるPhase analysisは壁運動の異常をより正確に反映し、特に下壁異常 の㛟索に優水ていた。

(3)心電図同期心Pool SPECT法によるS.V(1回拍出量)と他の方法との相関はC.A.G法との相関が非 常に高く、First Pass法、Multigate法は高めであった。

108． 先天性心疾患における右室機能評価

埼玉県立小児医療センター ○高橋晃 松本慎橋本正美池井勝美橋本宏

（目的）先天性心疾患における右室機能の評価として、ファーストパス法による右室駆出率（以下RVEF）を求 めている。しかし、この方法は静注時のボーラスの速度や三尖弁あるいは主肺動脈の認識によりROIの設定が異な クRVEFが影響を受ける。今回、右室の形態認識を高めかつ再現性のよいRVEFを得ることを目的とした。

（方法） 仮の右室 R O I を設定し時系列曲線（以下 T A C ）を作成する。T A C の立ち上がり f r a m e を右室流 入画像、仮 R O I 内の最高カウント f r a m e を右室充満画像、そしてこれらの差引画像から真の右室 R O I と主肺 動脈分岐部までの R O I を設定し T A C を R-R間隔で移動平均をとり補正曲線を作成し R V E F を求めた。

（結果）ＲＯI を設定する際バックグランドのカットオフレベルを１０％にすると一番再現性が良かった。また、 故意に主肺動脈分岐部まで入れることによって R V E F は低值傾向を示したがデータはより安定した。移動平均法を 取入れることによってボーラスのチェックもでき信頼性の高いデータが得られた。

109.

99m T c 一標識赤血球（R B C ）心プールシンチによる大動脈硬化度測定の基礎的検討 名古屋市立大学病院 中央放射線部 $\mathrm{O}$ 春藤英雄 竹内囊彦 柴田靖应 岩田宏道

【目的】大動脈硬化症は、他の䁃器動脈硬化症に先行すると言われていることから、大動脈硬化症の診断は、䑏器動脈硬

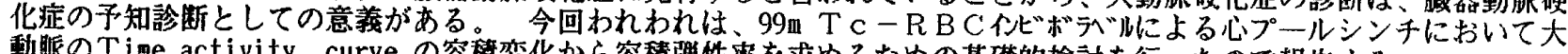

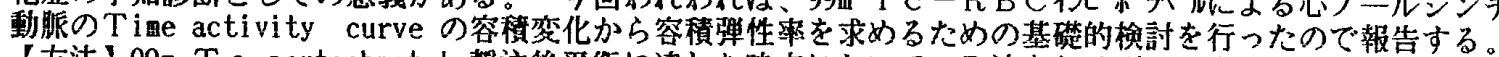

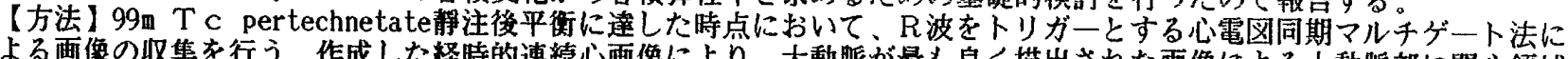
よる画像の収集老行う。作成した程時的連続心画像により、大動脈方最も良く描出された画像による大動脈部に関心領域 を設定し、このRＩにおける容積曲楾を作成する。容積曲線の最大計数と最小計数および上腕部の血圧をもとに容棈弹

【結果】大動脈部における関心領域（RＯＩ）の設定は、肺動脈部と大動脈部の境界を、シネモードおよびフェイズ解析

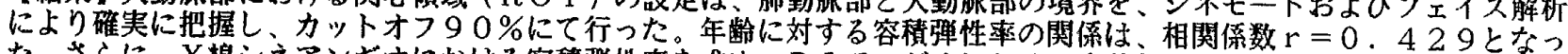
た。さらに、X楾シネアンギオにおける容楀弹性率を求め、RIアンキオにおける容積弾性率と比軨検討した結果、相関

\title{
110. R I アンギオによる術前化学療法の効果判定
}

(財) 癌研究会附属病院 アイソトープ部

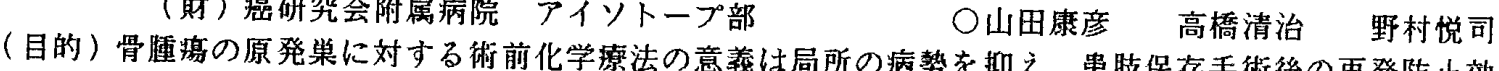
意舟は局所の病勢を抑之、患肢保存手術後の再発防止効果が举げら

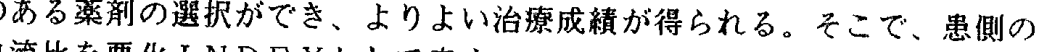

(方法) $99 \mathrm{~m} \mathrm{~T} \mathrm{C}-\mathrm{HSA}(555 \sim 740 \mathrm{MB}$ 悪化 I N D E Xとして表す。

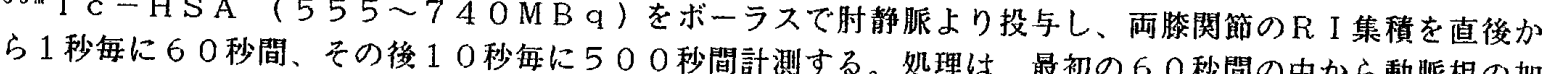
算画像を作成、次に 560 秒間全部の加算画儌间計测する。処理は、最初の 60 秒間の中から動脈相の加 X 1, I N DEX 2 とする。

(結果) 臨床所見と手術材料の組織検盉によって棇合的になされた効果判定が奻果有りのときは I N DEXが低く、 効果無しのときは高く变化していった。信頼性が高いと言われるゼログラフィとの相関も高いようである。 